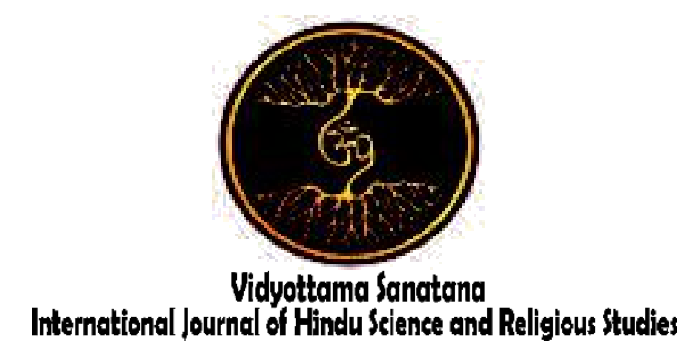

Vol. 4 No. 1 May 2020

\title{
YOGA PANDITA TEXTS AND CONTEXTS IN GRIYAS BULELENG REGENCY
}

\author{
By: \\ Luh Asli \\ STKIP Agama Hindu Singaraja \\ E-mail : luhasli212@gmail.com
}

Received: April 28, 2020

Accepted: May 21, 2020

Published: May 30, 2020

\begin{abstract}
This study aims to describe yoga pandita texts and contexts in Griyas Buleleng Regency. Yoga is increasingly more favorite among a large part of communities of the world crossing religious and cultural backgrounds It has become a lifestyle because of the benefits that the people who practice it. It is one of the spiritual assets and wisdoms of Hinduism offered to the world, not only in India, but also in Bali, both in terms of text and context. A number of texts in Bali contain theories and practices of what is called Yoga Pandita. The sources of this type are found and actualized within griyas. Actually, people havee taught Yoga Pandita since the emergence of griyas in Bali. Griya is a place in Bali where traditional Hinduism education takes place. A number ot texts such as Silakrama, Wrspati Tatwa, Sivasasana, Ganapati Tatwa are used as guides in actualizing yoga within the griyas. Most of the practices of Yoga Pandita in the griya areas especially in those in Buleleng regency tend to practice samyama or Raja Yoga and only a small part practices Hatha Yoga. This is caused by the factors such as age, degradation in physical ability, however in terms of mental ability and mind control and spirituality the people who practice yoga increasily more stable. This is a ladder in the esoteric world and is relevant in making progress of Astanggayoga in Patanjali Yogasutra.
\end{abstract}

Keywords: Yoga, Yoga Pandita, and Griya.

\section{INTRODUCTION}

Frosh stated that the rapid development of the technology of information is one of the factors causing people to be dynamic. As a result, people should adjust themselves to different changes. Several values which are 
currently established will tend to change, leading to psychological restlessness and crisis of identity (Linggih \& Sudarsana, 2020). Yoga teaches how to control mind as the highest sovereign of indria. Yogasūtra Patanjali Addyayah I.2 "Yogas Citta Vrtti Nirodhah", which means yoga is the control of the seeds of mind (Saraswati 1979). Mind as the king plays an important role and holds an extraordinary power that determines one's path in life many people because of inability to manage the directions of their thoughts have gone astray in their life. Also many people because of negative thinking suffer from distress, which is a source of many diseases. If mind as the king can be made calm, tamed, then other indriayas will be easily calmed down obeying the mind. Yoga is an interesting thing to discuss, because yoga is universal and quite popular among people both Hindus and other people. Yoga which is one part of sad darsana, is now studied by most of the world's population. Not only Hindus are interested in practicing yoga, but also many outsiders who are interested in practicing yoga (Sudarsana, 2019).

If observed from the perspective of the origin of yoga, it cannot be separated from the centers of spirituality such as India and Bali. To learn Yoga people tend to go to India or Bali. India and Bali have the same cultural spirit, that is, the cultural civilization of Hinduism. Bali as one region where Hindu culture develops is also the place of destination to learn yoga for those who love it this can be seen from the participants from a variety of nations who take yoga courses in various yoga group communities on the one hand, the term yoga is not new. In Bali, especially within the griya circle. Yoga has been practiced by the people in griyas even before the blooming of yoga as what we see today. Various questions arise like: why have the Hindus in Bali who have possessed the knowledge and who have practiced yoga earlier become the consumers rather than the center of the spiritual teaching or the places of famous yogis of the Balinese Hindus who learn yoga in their own place. In addition, the spiritual places in Bali are actually found mostly in griyas that spread over Bali, especially in Buleleng regency. The sentence "Ida kari meyoga" means the priest is practicing yoga. In other words, yoga is also practiced in griyas (Surada 2007). Hence, a priest has an obligation to practice yoga, in other words, the activity of yoga itselff is practiced in all griyas (Suhandana 2007).

There are two places to learn yoga in Bali. First in the yoga communities such as Yoga Band, Yoga BIF, Yoga Acro, Yoga Healing whose teaching tends to be limited to the mastery of Hatha Yoga and the second in griya areas as Hindu traditional education centers in which people learn Yoga Pandita (Atmaja \& Atmaja, 2013). The fact in the field shows that although the two places of learning teach yoga, the number of people who learn in griyas is not as great as that in the yoga community centers and the former is not as lively as the latter either. The latter also differ from each other based on their respective pioners. The difference in the participants between the two is very significant. Logically, there are yoga activities near home, but why bother to look for yoga in a farther place, paying more and some of the teachers are not Hindus, keeping in mind that yoga comes from the philosophy of Hinduism. There is a possibility that the sources of the yoga texts are different so that their actual practices are also different, and this causes a difference in their attractions. Thus people are more interested in the general yoga than the yoga practiced in the griyas in Buleleng Regency.

\section{METHOD}

The present study entitled "Yoga Pandita Texts And Contexts In Griyas Buleleng Regency", is a qualitative study. It is said so because a qualitative study results ini descriptive data in the form of written words as well as spoken data in the form of opinion/ideas and observable behavior of Yoga Pandita's activities. The data were not collected by statistical and numerical prosedure. This study needs more of kinds of data in the form of words, not numbers. The setting of this study is at the area of griyas in 
Buleleng regency. The data were collected using observation and interview. The behavior of the Panditas were observed during Yoga session, information were collected during the interview, and their sermon/Dharma wacana functioned as qualitative data in this study. The primary and secondary data which had already been collected were then verified by conducting, 1) data reduction, 2) data display, 3) data interpretation, 4) conclusion drawing (Huberman, 1992.) The data were then analyzed, interpreted and concluded generally. By analyzing the data scientifically, it is expected that the result of the study is objective.

\section{RESULT AND DISCUSSION}

\subsection{The Source of Yoga Pandita Text}

The sources of yoga texts that are used as guides by priests in Buleleng regency are varied. Some griyas use Patanjali Yogasutra and some do not know the source of the teaching. The use of source texts in the teaching of yoga Pandita is closely related to the status that is attached to the pandita sulinggih himself. From a number of texts presented in the interviews in the field a concept was obtained that the yoga texts fall into three categories: texts that are related to tatwa (philosophy), ethics and ritual. There are some texts that are also used as supplement in improving the priests' competencies to make their knowledge more comprehensive to be able to serve the people more optimally. To the text group tatwa are included among others Bhuwana Kosa, Tatwa Jnana, Wrhaspati tatwa, Ganapati Tatwa, Purwaka Bumi. To the text group ethics are included Sila Kramaning Aguronguron, Sva Sasana, Werti Sasana (Disdikdas Prov. Bali, 1990). While to the source of texts on the implementation of Upacara (ritual) are included Yama Purwana Tatwa, Siva Tatwa Purana, Sanghyang Swamandala. All of the text contents learned during walaka is a prerequisite for preparation to become sullingih/ Pandital priest. The teaching and application of the messages contained in all of the text, in principle, are aimed at strengthening a walaka's belief and commitment when becoming a pries or a pedisan is being performed. Diksa is an initiation ritual and is held when every Hindu who wants to improve his or her status of purity and the one who is entitled to do this is stated in Wrspatitatwa in sloka 25 " there are seven activities in performing Dharma: : Sila, Yadnya, Tapa, Dana, Prawrjya, Diksa, Yoga (Pudja 2000). The granting of a new name is called abhisekanama, according to the status of purity as seen by the Hindu community such as Pedanda, Pandita, Bhagavan, Rsi Bujangga.

In doing their obligations these people have to obey the dharma message contained in Wrspatitatwa in sloka 25 above (Pudja 1999). As people who are regarded as holy, they also build Griyas as places traditional education takes place in their service to the community at the diksa process, the priest candidate is blessed with a special mantra for the candidate and the mantra becomes a gift with its strength of blessing from a guru/nabe to his or her student. In addition, there are a number of messages and promises to be kept after the diksa is over. The mantra and the message of this guru is secret and becomes the isoteric basis of a priest on doing and practicing yoga. To be able to hold on to the guru's messages, the first step that has to be taken by a priest is to obey the messages of the contents of the texts that have been taught in the preparation for a walaka.

\subsection{Yoga Pandita Practice in Buleleng gency}

The form of yoga practice performed by Ida Panditas in griyas in Buleleng regency is inseparable from the educational programs with traditional patterns applied in the griya area. The practice is based on texts among the texts that are used as guides in yoga practices there are the most basic texts. Some priests use Silakrama and Wrspati Tatwa and some others use Wrspati Tatwa and Yogasutra Patanjali, both texts in general these texts state that there are two foundations for practicing yoga: Excotericc and Esoteric Guides (Iyengar 1996). Excoterically, a priest 
although has achieved a Sanyasin level, his or her physical body still needs maintenance, since it is the physical body that is the target of saranam sadhanam, which measn the physical body is an instrument to reach moksha. Thus, this physical body when one is still alive has to be taken care of to become healthy. Its existence is like the casing of a cell phone/garget to serve its function well. In a healthy body one finds a healthy soul in a conscious state. In performing his or her service a priest has to keep his or her physical health by practicing yoga, protecting the values of Dharma in his or her capacity as "Stithaprajnasya" or a wise man or woman as stated in t Bhagavadgita II.54 "Shitaprajnasya ka bhasa Samadhi sthabasya kesava sthita-dhih kim prabhaseta kim aseta vrajeta kim" Its translation is : the signs of a person who is already stable are firm and steadfast in faith in samadhi as seen from how the wise person talks, sits, and walks. While the esoteric foundation serves and aims to improve the spiritual quality of the priest and is related to the development of sakti and sidhis which are different from one priest to another. This depends on the level of seriousness, obedience in practicing the message from the guru/nabe and the text message (Pudja 1999).

The exoteric and esoteric foundations of a priest can be explained in the following figure

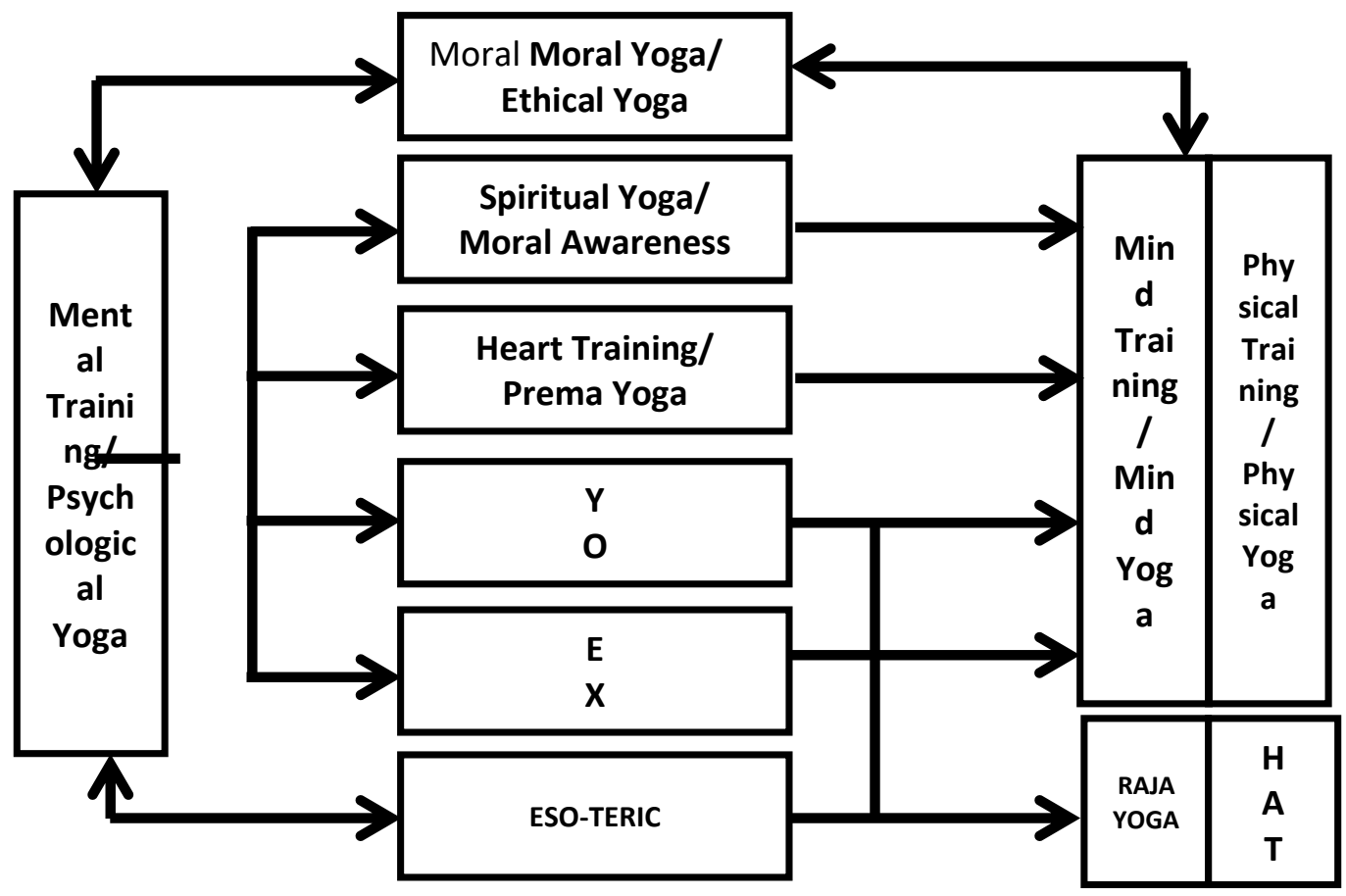

Figure 1. Diagram of the Foundation of Yoga Pandita Document: Private Property (2019) 
If looked at from the physical ability of a priest in practicing yoga, actually he or she is still able to perform some asanas in addition to the health/ exoteric needs. However, because of some reasons, then yoga practice is related to exercises in various asana poses which cannot be fully actualized at griyas. The data from the interviews at a number of griyas in Buleleng regency show that the practice of yoga done is only done is closely related to the obligations as priests, in this case the priest's activity of Nyuryasevana every day. Nyuryasevana is a priest's obligation to pray God with a number of mantras in a Padmasana sitting position at a holy place (merajan) to worship God for His greatnesss and love, to pray for the universe and its contents in order they keep living happily in peace. In such a process, meditation is also done with a full concentration continually hour after hour in the cakras of the body and this has an impact on the development of spiritual strength and sidhis of a priest. In doing his or her obligations, both at the time of nyuryasevana, ngeloka phalasraya, and meditaion he or she practices a padmasana body position that is a straight sitting posture with both soles of feet on both thighs. This position is a very beneficial and effective posture in practicing mediation, saying japas, leading a panca yadnya ritual for a male priest. While for a female priest, the posture of Wajrasana becomes the most comfortable and strong one to be practiced. As what most of the priests in Buleleng regency say, in addition to padmasana, they also practice asana Sidhasana, Silasana/swastikasana which are almost as beneficial as Padmasana (Menaka, 1983).

In addition to the reason that asana is required as one of the priest's daily obligations daily and that it is practiced only in a limited occasions, the one that is not least in importance is padmasana, silasana, swastikasana aand wajrasana positions that are very effective and will stimulate a miracle for a priest. This stage becomes a continuation in exploring the esoteric world. It is this stage that becomes the most often yoga position practiced by priests. This stage is called Samyama. Samyama of a practice of three final stages in Astanggayoga: Dharana, Dhyana and Samadhi. At this stage the one that can be useful is only asana, that is: Padmasana, Silasana, Swastikasana and Wajrasana. Dharana in Wrspatitatwa is explaned as : 'concentration of mind on $\mathrm{Om}$ Kara in the cakra of heart that will bring the priest to Siva who is transcendent, Dhyanayoga is an increasingly stable concentaration the same level as Dharana in which the concentration that keeps on being calm, increasingly stronger and does not change in a point. Samadhi is a concetration that only reflects in absolute sense, without any desire, without any characteristic/ object, pure, not hidden, focused and lies calmly in the absolute universal consciousness That is what is called actualization of samadhiyoga. This practice has surpassed the region of Hatha Yoga (Muktibodhananda, 1958).

The practice of yoga Pandita is closely related to the priest's competence as instructed in Saracamuscaya 40. that is : 1) as Satyadi, meaning that the priest has to reflect truth, both from inside in thought, that comes out in the form of speech / words, and more importantly in the form of deeds. The ideas, words and behaviors are regarded to represent the truth of a sacred book or the sayings of God. 2) as Sang Patirtan at ngarga tirta, a priest through certain mantra, yantra, and tantra has gone through a process of ngelinggihang God Siva in his physical body. In his or her strength and sidhi, a priest makes tirta that serves as purifier, neutralizer, all mala, pala, klesa, all roga, all wighna, and pataka. The belief and the spiritual strength of a priest is able to purify the universe, 3) as Sang Apta (Saraswati 1979). Meanings a priest has to speak the truth using true ways so that they are believed by the followers, in this case, a priest is positioned as a holy person, as one of the statuses of the spiritual guru which are used as model whose speeches are imitated by his or her followers, 4) as in Sang Panadahan Upadesa, which means the prist is regarded as God in sakala who gives a good example in life, so that such kind of 
priest deserves to be called Sad Guru or Sat Guru beside Adi Guru Loka (Venkateswarlu, 2012).

The competencies of a priest as stated in Sarasamuscaya text above is supported by many samyama exercises as the foundation of the esoteric practice of Yoga Pandita (Kajeng, 1999). The practices of the following positions are found in some griyas in Bulelng regency.

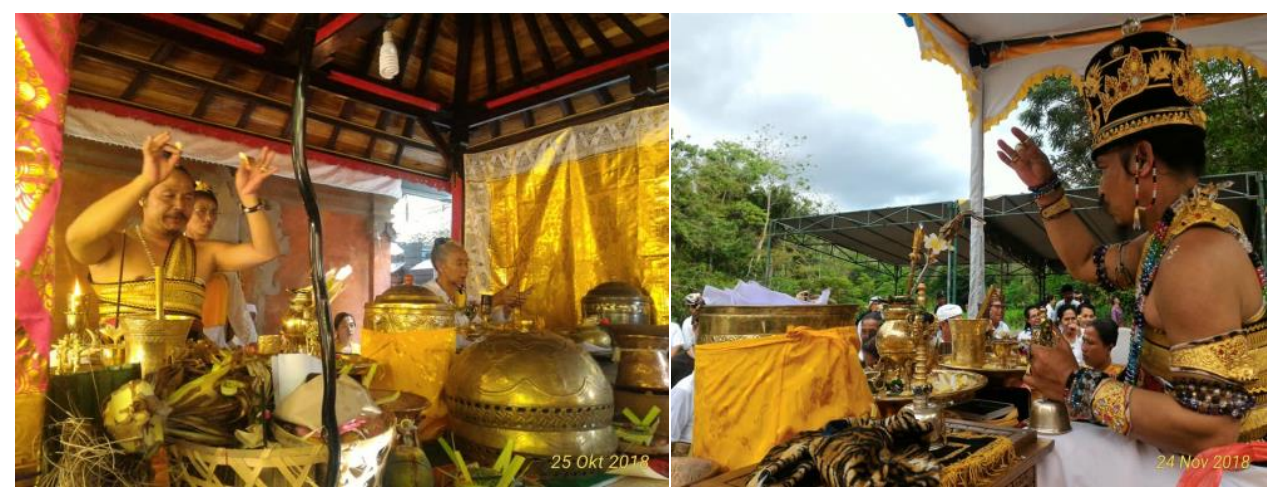

Figure 2. Yoga Pandita in Padmasana Position

Document Private Property (2019)

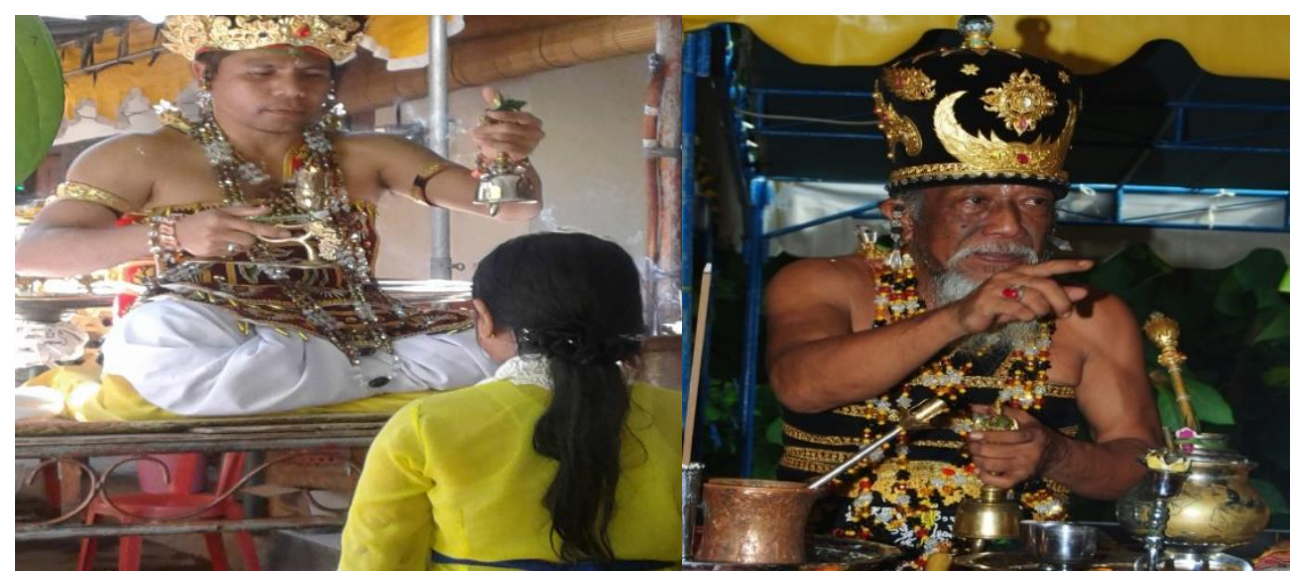

Figure 3. Yoga Pandita in Padmasana Position

Document Private Property (2019)

The position of the priest above is the positionn when he is preparing ngelokaphalasraya as one of the services to the community. In one of the positions, it is done simultaneously with the saying of puja mantra, mudra, mudra tangan, concentration of mind to Hyang Tunggal in the Padmasana position. As stated by Suryanarayana (2013) mind can be directed, controlled with japam, which in this study the saying of mantras in the stages of Dharana and Dhyana will bring one to the absolute realization. Such a position is a position in which a priest as a medium that will bring the offering of bhakti to the target of worship in accordance with the ritual held by Yajamana. As a medium it i believed by the Hindus, so that the quality of the seriousness of the concentration of relation with God will determine the success of prayer. The practice of Padmasana position at the same time with the saying of japam-mantra, the movement of hands in the shape of mudra, the concentation of the mind on God's radiance, indirectly has the impact on the activationof cakra energy along the backbone, in which along the backbone in the perspective of yoga psychology there are three main arteries that are connected to the stem of the neck.. Backbone is the strength that supports human body and a basis for the 
nerves from all over the body. Thus, the major cakra of the body will be activated when doing the simultaneous motion (Suryanarayana, 2013).
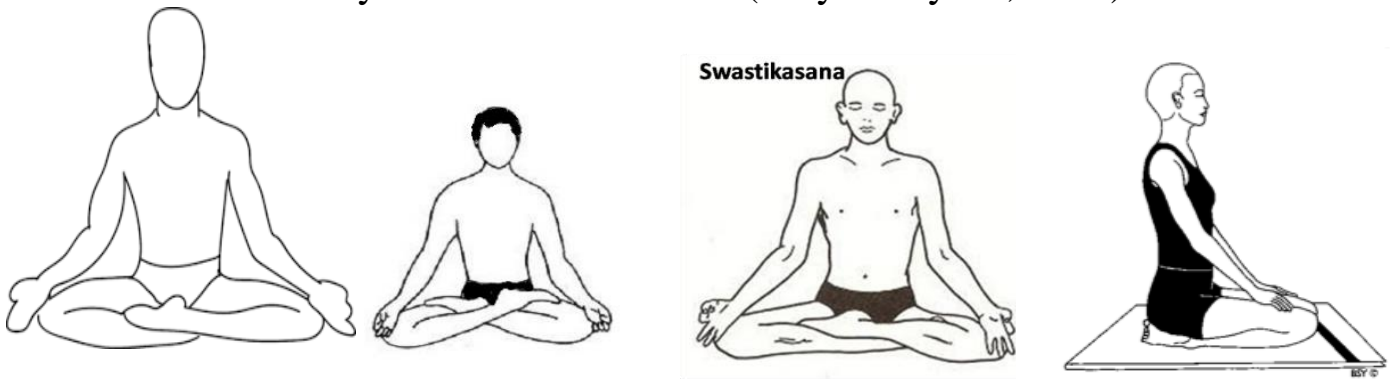

Figure 4. Padmasana and Swastikasana Positions.

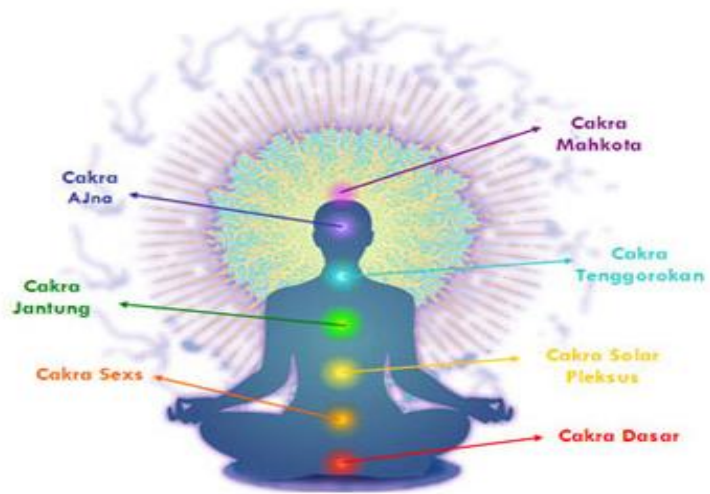

Figure 5. Sidhasana, Body Cakra, Wajrasana Position

Thus, the practice of Yoga Pandita that is done in the griyas in Buleleng Regency are the application of Yama-Nyama that is reflected in the basic obedience of a priest, Pranayama practice, asana, including only Padmasana, Sidhasana, Swastikasana, Silasana, and Wajrasana. However, there are one or two griyas that implement some positions of asana and this is only 2 percent of all griyas in Buleleng Regency. Prathyahara (mind entering indra/ ngeret indriya) becomes the requirement in the preparation of samyama. Samyama is the three final parts of the ladder of Astanggayoga Patanjali Yogasutra (Somvir, 2009). Regarding the rest, most tend to practice Samyama only every day with the Padmasana position, mantra, mudra since Yoga Pandita is the practice/ actualization of Raja Yoga that llies in the Esoteric level and it can only be practiced by a few people. Different from the practice in genral yoga in which more thant 90 percent practice Hatha Yoga and the benefit can be felt by the body directly (exoteric) not the dyatmika state /waskita state, spiritual acuteness, spiritual sensitivity. Thus, only some asanas are needed in relation to yoga Pandita.

\subsection{Theory of Yoga and Agil Structural Functional in Yoga Pandita}

Yoga extends multidimensional relationships, like circles formed from vertical and horizontal lines. Yoga is not just about body contortion in practicing a variety of difficult asanas, but also yoga is very closely related to the harmony of the body, mind and soul, when the body is sick and weak, then the mind, soul are also affected. Svami Sivananda, a yoga expert who has spread the teachings of yoga to various parts of the world states:

'... the body, mind and soul are very closely related each other. Asanas give strength, like a horse that carries to the final destination, Pranayama makes the body light, Pratyahara gives calm, Mudra gives determination, Dhyana gives an 
understanding of self, Samadhi gives the separation of gross and subtle bodies and where this state is very happy / cosmic consciousness (Sivananda, 2005)'

According to Selasih \& Sudarsana (2019), spiritual knowledge is basically full of excitement, unfortunately some individuals are not interested in learning it because they experience disorientation, as if material things are more pleasant. Both students who have felt half-knowledgeed or feel totally uninformed must be drawn with the allure of an alluring ashram. This technique is known in the Bhagavadgita as the concept of Jnana Yajna. In the teachings of Hinduism, this multi-dimensional relationship theory is more popular with Yoga Theory. When it is compared with the relationship in human life, it cannot be separated from the interaction with the environment where they live (Maslow, Abbraham 1994). As social creatures they will always be dependent each other. Therefore, the connection is a necessity. Parson's Structural Functional also calls it as the AGIL concept to maintain equilibrium (balance), so that harmony occurs (Raho, 2007).

Vertical relationship is a necessity in life, because from the perennial view all that exists in the universe is created and sourced from the Ultimate/ God centric namely God himself (Saputra, 2012). Therefore, there is no reason for humans not to connect vertically with their 'creator' and horizontally to nature as well as the horizontal relationship with each other (human being).This multidimensional relationship is reflected in Pandita yoga, which horizontally as the Sista, Upadira, which the status is as a saint who gives enlightens, inspires and opens the awareness and understanding of Hindus specifically and to others about his life and lives. Vertically, during his position as the ceremonial leader (the patirtan) mediates the yajamana's relationship with the worshiped God (dipa). This balance is reflected when Pandita performs mantras, mudras, yantras and tantras simultaneously in Yogasutra Patanjali called Samyamah (Dharana, Dhyana and Samadhi / Raja Yoga). The purpose of those mentioned is to recognize one's identity as a human being. By recognizing this truth, a balance/Homeostasis will occur. Balance will give serenity. Serenity is like clear water in a large jar that does not sway, and then the voice of truth will be perceived and understood properly. Yoga is the basis of a method that goes on like a circle throughout life and the final goal is the state without attachment to achieve freedom.

\section{CONCLUSION}

Yoga becomes a way to connect oneself with the universe and God through the control of motion mind waves. The mind as the sovereign of indras if can be tamed, the other indras will easily follow the mind. The mind is the big power in a person's life is very influential in determining his or her path in life. Yoga can learned in two places: first in the yoga centers in the yoga communities that are general in character and taught in sanggars, communities, formal institutions ad the second, yoga can be learned in the griya areas that are the traditional places in Bali to learn yoga. In the general yoga, the teaching is limited to Hatha Yoga, in a formal educational institution. Astanggayoga is generally practiced but mostly in the form of Hatha Yoga and especially in the griyas in Buleleng Regency, so far there has not anyone studying it up to this study was conducted. The result of this study shows that "Yoga has developed, practiced since the establishmentof griyas in Bali, and this yoga is called Yoga Pandita, the source of the texts that becomes the guide for practice Yoga Pandita is the text that is related to the three frames of Hinduism (Tatwa, Ethics and Ritual) in the form of lontars such as Wrspati Tatwa, Silakrama, Bhuwana Kosa, Tatwa Jnana, Wrhaspati Tatwa, Ganapati Tatwa, Purwaka Bumi, Sila Kramaning Aguronguron, Siva Sasana, Werti Sasana, Yama Purwana Tatwa, Siva Tatwa Purana, Sanghyang Swamandala.

The practice of Yoga Pandita in Buleleng Regency is closely related to the obligation of the priest such as in the implementation of Nyurya sevana (worshiping God, and praying 
for the happiness of the universe) and Ngelokaphalasraya (serving the community as the medium for Panca Yadya rituals) and all the competencies that are related to Saracamuscaya sloka 40. From the eight steps in the ladder of Yogasutra Patanjali, Samyama (Dharana, Dhyana, Samadhi) are the most frequently practiced in Yoga Pandita in griyas in Buleleng Regency, since the practice of Samyama can develop waskita, spiritual acuteness, and improvement of the spiritual quality of the priest. While for the general public, it is natural that this yoga is not attractive enough, since aa the Samyama practice level, only a few can do it, while most people are still in the tie wit the exoteric needs/ the physical / worldly needs.

\section{REFERENCES}

Atmaja, B. \& Atmaja, A. T. (2013). Reinterpretasi Bentuk, Fungsi Da Makna Ke Arah Kajian Budaya. Singaraja: Pascasarjana Undiksha.

Disdikdas Prov. Bali. (1990). Kekawin Bomantaka. Denpasar: Departemen Agama Republik Indonesia

Iyengar, B. K. S. (1993). Light on the yoga sutras of Patanjali. Aquarian/Thorsons.

Kajeng, I N. (1999). Sarasamuscaya. Surabaya: Paramita.

Linggih, I. N., \& Sudarsana, I. K. (2020). The Dynamics of Rejang Renteng Dance in Bali as an Intangible Cultural Heritage of the World. Space and Culture, India, 7(4), 45-58.

Maslow, Abbraham. 1994. Motivasi Dan Kepribadian (Teori Motivasi Dengan Pendekatan Hierarki Kebutuhan Manusia). Bandung: PT Pustaka Binaman Pressindo.

Menaka, I M. (1983). Kekawin Arjuna Wiwaha, Dengan Arti Dan
Keterangan. Singaraja: Yayasan Kawi Sastra Mandala.

Muktibodhananda, S. (1958). Hathayoga Pradipika (Light On Hathayoga of Comentary). Bihar-India: Yoga Publication Trust Yoga Vidya.Com.

Pudja, I G. (1999). Bhagawad Gita (Pancama Veda). Surabaya: Paramitha.

Pudja, I G. (2000). Manawa Dharmasastra. Surabaya: Paramitha.

Raho, B. (2007). Teori Sosiologi Modern. Jakarta: Prestasi Pustaka Karya.

Saputra, R. (2012). Tuhan Semua Agama. Yogyakarta: Lima.

Saraswati, S. S. P. (1979). Patanjali Rajayoga. Surabaya: Paramita.

Selasih, N. N., \& Sudarsana, I. K. (2019). Pembelajaran Berbasis Pasraman: Membangun Karakter Remaja. Jayapangus Press Books, i-99.

Sivananda, Sri Swami. 2005. Pikiran Dan Misteri Penaklukannya. Surabaya: Paramita.

Somvir. (2009). Mari Beryoga. Denpasar: Yayasan Bali-India.

Sudarsana, I. K. (2019). Developing Spiritual Behavior through Yoga Training. Vidyottama Sanatana: International Journal of Hindu Science and Religious Studies, 3(1), 24-30.

Suhandana, A. (2007). Diksa Pintu Menapaki Jalan Rohani. Surabaya: Paramitha.

Surada, I M. (2007). Kamus SanskrtaIndonesia. Surabaya: Paramita.

Suryanarayana, N. (2013). Mind and Meditation. International Journal of Multidisciplinary Educational Research 2, 13(1), 181-187.

Venkateswarlu. (2012). Yoga For The Purification of Mind. International Journal of Multidisciplinary Educational Research 1(2): 379-86. 